4Morse, P. M. and H. Feshbach, 1953. Methods of theoretical physics, part. 1. McGrawHill, 997 pp.

'Batchelor, G. K. 1967. An introduction to fuid dynamics. Cambridge University Press. $615 \mathrm{pp}$.

'Montgomery, R. B. 1969. The words Naviface and Oxyty. Journal of Marine Research, 27: 161-62.

7 Jaeger, J. C. 1956. Elasticity, fracture and flow. Methuen \& Co. 152 pp.

\section{Growth of Spruce \\ at Dubawnt Lake, Northwest Territories}

The interesting note by Hansell et al. ${ }^{1}$ on tree growth at Dubawnt Lake and on my statements concerning trees at Dubawnt, Ennadai, and Yathkyed Lakes ${ }^{2}$ requires comment. Let me briefly state a few points: 1) The concept "tree line" is confusing since a lone tree far beyond the forest border must be included within the "treed" zone; 2) Dwarfed and decumbent black spruce (occasionally white or "intermediate" forms) exist over a wide zone north of the forest border in Keewatin and Eastern Mackenzie; individuals in favoured sites attain "tree" size ( $\geqq 3$ inches in diameter breast height, $d b h$ ); 3) While reproduction is primarily by layering (in black spruce at least), seedlings are consistently seen (I have a photo of one at the head of a grave on a hilltop at Ennadai, a site apparently rendered temporarily favourable by a picket enclosure); 4) Seedling mortality in all species in these areas is high, but species survival is most markedly conditioned by the frequency with which very severe seasons occur (i.e., a series of very cold summers); 5) Seedlings that survive a series of favourable years can then live and grow through a fairly long series of rather severe years; 6) At Ennadai and elsewhere, apparently anomalously successful young trees are in places found on exposed sites; they are not, however, a sure sign of a major climatic amelioration but of a few favourable years; 7) An extension of range of "trees" over a few miles, thus, does not in itself, to me at least, constitute indisputable evidence of an extension of the "tree line" especially if this has occurred within the existing range of spruce as a species; 8) The map as presented (p. 233) shows, in my view, the northward extent of the range of spruce, anywhere within which will be found the occasional "tree" on favoured sites, the result of some sequence of events permitting the individual to grow but not necessarily a general change in climatic conditions; 9) $\mathrm{A}$ much better indication of climatic change would be a shift in the position of the forest border, defined as the area where the (gently rolling) terrain is 50 per cent covered by forest and 50 per cent by tundra (for my delineation see Bryson ${ }^{3}$ and Larsen 4,5$)$; 10) The comment that I say spruce has not re-established at Ennadai Lake is very misleading since I wrote that spruce is common at Ennadai Lake (part of which lies south of the forest border); my reference was to a grove of spruce (at the northern largely barren end of the lake) cut by natives many years ago which has not regenerated; 11) There is, in fact, a grove of spruce with individuals of $\mathrm{dbh} \geqq 3$ inches and basal diameter of $\geqq 8$ inches near Yathkyed Lake (at $62^{\circ} 35^{\prime} \mathrm{N}$., $98^{\circ} 52^{\prime} \mathrm{W}$.) which would put the "tree line" far out into the barrens on the map as presented; 12) There is also a grove of spruce near the outlet of the Kamilukuak River (south end of Dubawnt at $62^{\circ} 41^{\prime} \mathrm{N}$., $101^{\circ} 33^{\prime} \mathrm{W}$.) larger and with larger individuals, if memory serves, than any mentioned in the literature.

These points are not to be interpreted as disbelief in climatic change. I agree, in general, with the summary Hansell et al.1 present of recent climatic events. The topic invites speculation and, above all, more comprehensive field data from many places.

\section{James A. Larsen \\ University - \\ Industry Research Program University of Wisconsin}

\section{REFERENCES}

${ }^{1}$ Hansell, R. I. C., D. A. Chant, and J. Weintraub. 1971. Changes in the northern limit of spruce at Dubawnt Lake, Northwest Territories. Arctic 24 (3): 233-34.

2Larsen, J. A. 1965. The vegetation of the Ennadai Lake area, N.W.T.: Studies in subarctic and arctic bioclimatology. Ecological Monographs 35 (1): 37-59.

3Bryson, R. A. 1966. Air masses, streamlines, and the boreal forest. Geographical Bulletin 8 (3): 228-69.

4_. 1971. The vegetation of Fort Reliance. The Canadian Field Naturalist 85 (2): 147-78.

5 __. In press. The forest-tundra ecotone; chapter in Arctic and Alpine Research, edited by Roger Barry. London: Methuen. 